\title{
Food and medicinal relevance of Cucurbitaceae species in Eastern and Southern Africa
}

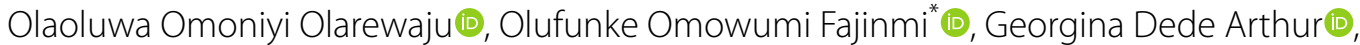 \\ Roger Murugas Coopoosamy ${ }^{0}$ and Kubendran Kista Naidoo* (i)
}

\begin{abstract}
Background: The traditional use of medicinal plants is an integral part of African culture and plays a major role in African societies. For centuries, plants have been used to cure diseases and till date, a vast majority of the African people especially in rural communities depend on the use of medicinal plants for the treatment of various ailments.

Main body: The Cucurbitaceae family has a diversity of medicinally relevant species which also play significant roles in food security in Africa. While some are underutilised and are sourced from the wild, others are domesticated and cultivated for food. This review therefore highlights the significance of Cucurbitaceae species in Eastern and Southern African countries. The use of various species in the traditional food and medicine systems of these countries is documented. The review further discusses some poisonous species with close resemblance to edible plants. The fatal effect of consuming any part of such plant species like young or old leaves and unripe fruit is highlighted.
\end{abstract}

Conclusion: This review is thus a documentation of the crucial role of Cucurbitaceae species in food security, treatment of a variety of diseases and its negative effect on humanity and livestock.

Keywords: Medicinal plants, Traditional food, East Africa, Southern Africa, Food security, Cucurbitaceae

\section{Background}

Cucurbitaceae (the gourd family) is a family of plant species with global pharmacological and dietary importance. Several members of the family are native to Africa and make one the most important plant family in existence with global impact due to its vast medicinal usage. It has about 800 species and 130 genera distributed mainly in tropical and subtropical regions of the world (Dhiman et al. 2012; Schaffer and Paris 2003). The family is often referred to as cucurbits (Dhiman et al. 2012).

The fruit, seeds, and leaves of some Cucurbitaceae species are traditionally consumed in various ayurvedic preparations and confectionaries (Dhiman et al. 2012).

\footnotetext{
*Correspondence: funkefajinmi@gmail.com; kuben@mut.ac.za Department of Nature Conservation, Faculty of Natural Sciences, Mangosuthu University of Technology, Durban 4031, South Africa
}

Three genera including Cucumis (cucumbers, melons), Cucurbita (pumpkins, squash), and Citrullus (watermelons) are among the top ten economically important vegetable crops of the world while several other members have regional importance (Schaffer and Paris 2003). These groups of plants have been playing important roles in food and traditional medicine for decades which makes them highly relevant in the history of the African people.

\section{Food and medicinal use of Cucurbitaceae species in Eastern Africa}

Use of Cucurbitaceae species in traditional food and medicine systems in Ethiopia

Ethiopia is an old country with the ancient use of Cucurbita pepo leaves for the treatment of dandruff (a skin condition that mainly affects the scalp) in the Ghimbi 
district, southwestern Ethiopia (Meragiaw et al. 2016). Coccinia abyssinica is used to treat gonorrhoea, tuberculosis, and cancer in Wollega, Ethiopia. It is used during traditional ceremonies and celebrations (Gelmesa 2010). Oral administration of cultivated seed of C. pepo is used for the treatment of gonorrhoea in the Ghimbi district of southwestern Ethiopia (Abera 2014). Cucumis prophetarum Linn. fruit is used as an abortifacient in women and to hasten placenta expulsion in cows (Wickens and Burkill 1986). Momordica foetida Schumach. young leaves are cooked and eaten while the endocarp is eaten raw in the Bullen district, north-western Ethiopia (Berihun and Molla 2017). Fresh Cucumis ficifolius A. Rich. is a wild edible plant used in Quara district, northwest Ethiopia (Tebkew et al. 2018), while boiled whole fruit of Coccinia grandis L. Voigt and leaves of Kedrostis foetidissma Jacq. Cogn. are eaten as vegetable but are sourced from the wild among the Kara and Kwego people of Ethiopia (Teklehaymanot and Giday 2010). Coccinia abyssinica tuberous roots are cooked and eaten (Asfaw 1997).

Food and medicinal use of Cucurbitaceae species in Kenya Young leaves of Coccinia grandis, C. trilobata, Cucumis dipsaceus, Kedrostis gijef, K. pseudogijef and Lagenaria siceraria are some of the indigenous leafy vegetables consumed in Kenya (Grosskinsky and Gullick 1999). Young leaves and seeds of Momordica rostrata are edible. The seeds are sometimes roasted while the leaves may be mashed with maize and beans (Grosskinsky and Gullick 1999). Citrullus lanatus, Coccinia grandis, Lageneria siceraria, Momordica rostrata are used as non-leafy indigenous vegetables in Kenya (Grosskinsky and Gullick 1999). The leaves of Kedrostis foetidisimma and the bark and twigs of Cucurbita maxima are used as vegetables or additives in food preparation in the AbaWanga community of western Kenya (Shiracko et al. 2016). Similarly, the young leaves and soft tips of Kedrostis pseudogijef are consumed as a vegetable while the fruit is also edible, but the water used in boiling the fruit is normally discarded. The plant is also used in performing a ritual before moving cattle to a new area (Ngugi et al. 1999). The roots of Momordica rostrata A. Zimm. are used to treat the symptoms of tuberculosis in Kenya (Amuka et al. 2014). Fruit of Coccinia grandis is eaten raw while the young leaves are usually cooked as a vegetable. The leaves of the plant mixed with ghee are used as medicine for pain on the left side of the stomach and paling of the body in children (Ngugi et al. 1999).

\section{Use of Cucurbitaceae species in Uganda and Rwanda}

Species such as Kedrostis foetidissima Jacq. Cogn. is mixed with silverfish, boiled, and given to children to drink for measles treatment while Momordica feotida
Schumach is pounded, mix with water, and used to bathe to remove body odour in communities around the Mabira Central Forest Reserve, Uganda (Tugume et al. 2016). The leaves of Lagenaria sphaerica Sond. Naudin and Momordica foetida Schumach. are used to treat the symptoms of tuberculosis in Uganda (Bunalema et al. 2014). Zehneria scraba leaf juice is used to treat mumps, and Momordica foetida leaves are taken orally to stop vomit in the Buhanga Sacred Forest which is a relict forest of tremendous ecological importance to Rwandan society located in the Musanze District (Irakiza et al. 2016). Cucurbita pepo is used as food and medicine, and has cultural relevance in Rwanda. Momordica foetida Schumach. leaves are used to treat symptoms of tuberculosis in Rwanda (Desouter 1991).

\section{Use of Cucurbitaceae species in Tanzania}

(Ruffo et al. 2002) listed Coccinia grandis, Cucumis dipsaceus, Kedrostis leloja, Momordica rostrata, and Peponium vogelii as part of edible wild plants of Tanzania. The ripe, red fruit of Coccinia grandis is collected and eaten raw or peeled and cut into small pieces and mixed with porridge. The fruit and leaves of Cucumis dipsaceus are sold in local markets in Tanzania. The tender leaves and young shoots of $C$. dipsaceus are chopped and cooked with coconut milk or groundnut paste and served with a staple. The tender leaves are sun-dried and pulverised, then soaked in hot water, boiled, stirred, and served with a staple. The leaves and roots are pounded and used as a poultice for the treatment of wounds. Juice from the fruit is supplemented with fresh milk and used as an antidote for poisoning. Similarly, the leaves of Kedrostis leloja are chopped and cooked with coconut milk or pounded groundnuts and eaten with a staple. Its ripe fruit is fleshy and consumed raw, especially by children, while the plants are used as fodder. The ripe fruit of Momordica rostrata is cut in half and its juicy pulp eaten by children. The tender leaves may be cooked alone, or with other vegetables such as amaranth and peas. Its fruit is boiled before consumption. The plant is also used for ornamental purposes. The powder obtained from peeled and dried roots is used to preserve cereals due to its potency against stalk borers (insect pest that attacks most cereal crops). Ripe fruit pulp of Peponium vogelii is sweet and eaten raw, especially by children and herdsmen. The leaves are used to alleviate menstrual problems. Peponium vogelii fruit is used as fodder for rabbits and pigs.

The leaves of Momordica foetida and seeds of Telfairia pedata are used as food in the Kilombero Valley, Morogoro Region of Tanzania (Salinitro et al. 2017). Leaves of Momordica charantia L. 'Kabindizi' are used to treat malaria and are sold in the Tanzanian medicinal plant market (Hilonga et al. 2019). Fruit of Coccinia adoensis 
is eaten in Tanzania (Bosch 2004). Cucurbita pepo L. is used to prevent pregnancy while Telfairia pedata $\mathrm{Sm}$. Hook. is used in caring for new-born babies. Women consume T. pedata before and after childbirth because it is a good source of protein and helps in milk production for suckling babies (Lindh 2015). The plant is also used to treat sepsis rupture in the Dar es Salaam region (Lindh 2015). Telfairia pedata (oyster nut) is a perennial plant grown in Central and East Africa (Ng 1993). It produces very large, long, flat seeds and tastes like almonds when roasted (Ng 1993). Telfairia pedata is one of the indigenous forest food plant species from the Uluguru North and West Usambara Mountain which provide the people with edible nuts and seeds (Msuya et al. 2010). In tropical East Africa, T. pedata seeds are used to make oil and are roasted and eaten (Schaefer and Renner 2011). Lagenaria breviflora (Benth.) Roberty is used as a purgative in Tanganyika, Tanzania (Wickens and Burkill 1986).

\section{Use of Cucurbitaceae species in Mozambique}

In Mozambique, the roots of Cucumis hirsutus Sond. are used to treat stomach-ache (decoction or infusion, oral), vomit (decoction or infusion, oral), fontanelle syndrome (macerated in water or mush, oral or as food), female infertility (macerated in water, oral) while the bark, leaves, and roots of Momordica balsamina L. are used to treat malaria (decoction or cooked, oral or as food) and general weakness (cooked as food) in Muda, Mozambique (Bruschi et al. 2011). Citrullus lanatus Thunb. Matsum. et Nakai fruit is applied topically to treat bandama. Fruit of Lagenaria sphaerica Sond. Naudin is also used to treat bandama using the direct application method and to close fontanelle (direct application) in Muda, Mozambique (Bruschi et al. 2011).

\section{Food and medicinal use of Cucurbitaceae species in southern Africa}

\section{Use of Cucurbitaceae species as food in Zimbabwe}

The kernels of Citrullus lanatus are edible and are grounded into a paste before consumption. The paste may also be mixed with other food items before consumption. Roasted and salted seeds of Cucurbita maxima are enjoyed by the Shona and Ndebele people of Zimbabwe. The seeds are sometimes grounded coarsely into a paste and moulded into balls (Gomez 1989). Cucumis anguria is used as a vegetable in the Nhema communal areas of Zimbabwe (Maroyi 2012). In Ruwangwe, Zimbabwe, leaves of bitter forms of Cucumis anguria are cooked and eaten like pumpkin leaves (Cucurbita spp.). This preparation is known as 'mubvororo' and is usually a special dish prepared for the head of the household (Wilkins-Ellert 2004).

\section{Use of Cucurbitaceae species in South Africa}

Cucurbita pepo, C. maxima and C. moschata (pumpkins), Citrullus lanatus and Cucumis melo (melons), and Momordica balsamina (balsam pear) are leafy vegetable species common in South Africa (Hart and Vorster 2006). Cucurbita pepo is often consumed as a vegetable and is a vital component of the local diet and economy of the Vhavenda people (Constant and Tshisikhawe 2018). Cucurbita pepo leaves are eaten like spinach when cooked with the roots and consumed with porridge. The leaves are cooked with pumpkins and flowers as a dish while the flowers alone are dried and used as a vegetable (Constant and Tshisikhawe 2018). The fruit of Cucumis metuliferus E. Mey. ex Naudin is consumed as a vegetable (van Wyk 2011). The fruit (non-bitter type) of Cucumis zeyheri Sond. is used to make jam while its leaves are utilised as food (van Wyk 2011). Similarly, the young fruit of Langaneria siceria and fruit and leaves of Momordica balsamina are sources of food.

Momordica balsamina L. Tshibavhe is used as food and medicine. The leaves are both consumed raw or cooked as a soup and consumed with porridge. The leaves have a piquant taste when cooked with other vegetables. The leaves are used in the treatment of high blood pressure and as an antiemetic (Mabogo 1990). Leaves of Momordica boivinii Baill. are used as a vegetable which is mostly eaten in times of drought. It is eaten with porridge or used as a spice. The leaves and roots are used for the treatment of earache and gout. It is alleged that the roots help babies to grow bigger (Mabogo 1990). Momordica balsamina has been reported to be effective in the treatment of diabetes (van Rooyen 2001). The plant emits a strong unpleasant smell when bruised (Watt and BreyerBrandwijk 1962). A liniment, made by infusing the fruit exclusive of its seeds in olive oil or almond oil, is used to soothe chap hands, burns, and haemorrhoids while the mashed fruit is used as a poultice (Deutschländer et al. 2009). Leaves of Cucumis africanus L. are used as a vegetable or mixed with Hibiscus trionum and eaten together with porridge. The seeds are used as a purgative (Mabogo 1990).

Cucumis myriocarpus subsp. leptodermis is used in the Seklmkhune and Waterberg districts while Citrullus lanatus Thunb. Matsum. and Nakai is used in the Waterberg district to treat sexually transmitted infections (Semenya et al. 2013). Fresh leaves of M. balsamina are boiled in water and used to treat hypertension in Maputaland (de Wet et al. 2016). The pounded dried root of Cucumis metuliferus E. Mey. ex Naudin is used to treat asthma in the Limpopo province of South Africa (Semenya and Maroyi 2018). The leaves of Cucurbita pepo and Momordica boivinii are believed to shrink in size if touched or harvested by menstruating women 
(Constant and Tshisikhawe 2018). Among the Xhosa people, an infusion of the tuber of Kedrostis foetidissima Jacq. Cogn. is used as a ritual wash for luck. A small piece of the tuber is held under the tongue in dangerous or troubled times such as in a court of law (Cocks and Dold 2006).

\section{Use of Cucurbitaceae species in Congo}

The plant is mostly cultivated in the Bas-Congo province of the Democratic Republic of Congo, and it is mostly used as source of food (Schaefer and Renner 2010). It may be prepared in combination with Cucumeropsis mannii seeds and caterpillars, grasshoppers, shrimp, or winged ants as a meal (Adriaens 1951). Cucurbitaceae species such as Cucurbita moschata, Cucurbita pepo and Lagenaria siceraria are cultivated for food and medicinal purposes (Issali et al. 2020). Momordica foetida is used for treating malaria in Bukavu city (Kasali et al. 2014). Luffa cylindrica is widely used to treat abscesses and kill filarial in the country (Wickens and Burkill 1986).

The seed of Cucurbita pepo Linn. when mildly roasted and crushed in water can be given to women during childbirth to aid smooth delivery (Wickens and Burkill 1986). Palm oil is added to crushed leaves of Lagenaria siceraria (Molina) Standl and used to treat urticaria caused by caterpillars in the Republic of Congo (Wickens and Burkill 1986). The fruit of Cucumis sativus L. Concombre (Français) is used to treat diabetes in Lubumbashi region of the country (Scheub 1985). The roots of Cogniauxia podolaena Baill. are used for the treatment of fibroma, myoma, cyst and malaria in Congo Brazzaville (Ngbolua et al. 2016). However, Cogniauxia podolaena was reported to be toxic and it is therefore important that the people are well informed about the possible toxicity dangers associated with its use (Ngbolua et al. 2016).

\section{Use of Cucurbitaceae species in Namibia}

Acanthosycios naudinianus Sond. C. Jeffrey is used for treating mental illnesses in the Oshikoto region, Namibia (Cheikhyoussef et al. 2011). Its tubers, stems, and leaves are crushed and soaked with water with the resulting infusion taken orally to alleviate gonorrhoea or to wash affected skin or body sores and fungal infection of the skin in the management of HIV/AIDS-related diseases in Rundu, Kavango East Region in Namibia (Chinsembu et al. 2015). Roots of Cucumis africanus L. f. are cut into small pieces, macerated in water and the infusion is administered orally to treat infections such as gonorrhoea, liver problems, jaundice, boils, cancer, and tuberculosis in Rundu, Namibia (Chinsembu et al. 2015). Acanthosycios naudinianus is used as an anti-venom for beetle poisoning in Namibia (Leffers 2003). The seeds of A. naudinianus are exclusively collected from the wild and its mature fruit may be consumed raw or roasted. The unripe fruit of the plant causes a burning sensation of the tongue and lips when eaten raw (Bosch 2004). The fruit is an important source of water. The peel and seeds of the fruit may be roasted and pounded to make a meal. The tuberous roots are poisonous and have been reportedly used for homicidal purposes in Zambia (Bosch 2004). The seeds of Acanthosicyos horridus Welw. ex Hook. f. is referred to as butternuts or butter pips in Namibia (Wilkins-Ellert 2004). The seeds are either eaten fresh or roasted as a snack or ground into flour and cooked (Wilkins-Ellert 2004). They are used as a substitute for almonds and are exported to bakeries in Cape Town for confectionery use (Wilkins-Ellert 2004). Some of the plants produce bitter fruit because of a high cucurbitacin B and D content. Ripe fruit, which is sweet and juicy, weighs about $900 \mathrm{~g}$ and is either eaten raw and relished for their high-water content or preserved as flat cakes by drying (Wilkins-Ellert 2004). The young stem tips are browsed by livestock while the bitter roots have medicinal value and are either chewed or made into a decoction to treat nausea, stomach-ache, venereal diseases, kidney problems, arteriosclerosis, and chest pains. The crushed root is mixed with fat and used to treat wounds (WilkinsEllert 2004). Oil derived from raw or boiled seeds is used as a skin moisturiser and to treat sunburn (Wilkins-Ellert 2004). The preparation and use of arrow poison from the roots of $A$. naudinianus are common among the Bushmen tribes in Angola, Namibia, and Botswana (Bosch 2004).

\section{Poisonous plants in the Cucurbitaceae family}

Consumption of some species as food or medicine without proper identification could be dangerous, as some poisonous wild species share a close resemblance with edible ones. Caution must be taken when harvesting members of the Cucurbitaceae for food or medicinal purposes as cases of food poisoning, in both humans and domestic animals, have been reported (Verdcourt and Trump 1969). In some cases, species are so similar in vegetative morphology that the flower and fruit characters are the only means to distinguish between species (Chan et al. 2014). Not all member species have been investigated for toxicity and safety for human consumption.

\section{Incidences of poisoning and/or mortality from some Cucurbitaceae species}

There are reports of human toxicity due to the consumption of some cucurbits (Chan et al. 2014) in different parts of the world. For instance, several herbarium specimens are samples related to police investigations in the East African Herbarium (EA, National Museums of Kenya). Similarly, the roots of Momordica foetida 
Schumach. used to treat malaria led to the death of a patient in Kisii-Ahero, Kenya (police/anon. 1424/1971). A woman who was given a decoction prepared from crushed and boiled fruit of Cucumis dipsaceus Ehrenb. ex Spach. as medicine was later reported dead (Aldous et al. 1994). The leaves of Momordica friesiorum (Harms) Jeffrey are said to be extremely poisonous and known to kill cattle if eaten. Excessive consumption of Luffa echinate (Bristly luffa) fruit led to serious abdominal pain, vomiting, and bleeding about $20 \mathrm{~h}$ after consuming 100$150 \mathrm{~g}$ of dried fruit soaked in water (Khan et al. 2003). This caused deranged liver function, with recovery after 10 days after receiving intravenous fluids, one unit of whole blood infusion, and administrations of fresh frozen plasma, vitamin $K$, vasopressors, and proton pump inhibitors (Nadkarni et al. 2010). The cases of Cucurbitaceae poisoning are not well documented in Africa but are generally known in African societies, especially in rural communities that unripe fruit are bitter and poisonous. However, there are several reports of Cucurbitaceae poisoning in the developed world. In Alabama (1981-1982) and California (1984), a total of 202 incidences of human poisoning were reported from the consumption of bitter zucchini, a Cucurbitaceae member (Puri et al. 2011). Similarly, five cases were reported of bloody diarrhoea due to consumption of colocynth (Hansan 1985). The bitter taste is caused by cucurbitacin which is a toxic substance present in unripe cucurbits (Lavie et al. 1964).

\section{Compounds responsible for toxicity and poisoning}

Cucurbitacins are naturally occurring toxic compounds classified as tetracyclic triterpenoids (Chambliss and Jones 1966). They are found in Luffa cylindrica (L.) M.J. Roem. and several other species of Cucurbitaceae (Toteja et al. 2012). Several isolated and characterised Cucurbitacins such as Cucurbitacin A, B, C, D, and E (Usman et al. 2015) have been reported in the scientific literature. Cucurbitacin is used to protect plants from herbivores and is used functions as a repellent to most insect species (Usman et al. 2015). There is a need for the public to be educated that bitter bottle gourd juice (Usman et al. 2015) and fruit should not be consumed as the unpleasant taste is an indication of the presence of Cucurbitacins.

\section{Cucumis metuliferus, a poisonous yet edible species of Cucurbitaceae}

Cucumis metuliferus grows naturally in African countries such as Botswana, Namibia, Nigeria, Senegal, South Africa, and Swaziland (Wickens and Burkill 1986). However, this species grows in areas that are either shallow or deep with well-drained sand, riverbeds, or flood plains (Maundu et al. 2009). According to (Maundu et al. 2009), the unripe fruit of Cucumis metuliferous is poisonous, but edible and free of toxins when fully ripe. The fruit is bright orange when ripe, covered in sharp spikes, and a bright green, gelatinous flesh and the taste has been described as a combination of cucumber and banana (Isabirye 2019). It is often eaten raw, as a snack, or used in cooking (Teffera 2006). Cucumis metuliferus is common in markets in southern African countries such as Zimbabwe, Zambia, Mozambique, Malawi, and South Africa (Teffera 2006).

\section{Conclusions}

The Cucurbitaceae family has a wealth of species of great medicinal value which have played vital roles in the traditional medicine systems all over Africa. In some African countries, this family is used as local food in form of vegetables or side dishes thus, addressing food and nutritional security in African communities. Some Cucurbitaceae species have been used for food since time immemorial either as domesticated and cultivated species or as food sourced from the wild.

Also, effective taxonomy keys should be developed to differentiate between poisonous and edible species. Some species produce poisonous fruit if eaten unripe, thereby causing serious health issues or in worst situations leading to death. This can be avoided if the government engage in awareness campaign to educate the rural communities especially about poisonous plants that exist in the wild. In addition, the nutritional value of the edible Cucurbitaceae species should be highlighted in this campaign as the Cucurbitaceae species are part of the edible vegetables often sourced from the wild by rural dwellers. An in-depth postharvest study of the suitable storage conditions and food preparation/ processing methods that will help to maximise the vegetables/fruit and reduce the Cucurbitacin levels is crucial. These steps will help to maximise the potentials of Cucurbitaceae species as indigenous food and medicinal resource.

Acknowledgements
Mangosuthu University of Technology is gratefully acknowledged for funding.

Authors' contributions

$\mathrm{OOO}$ and OOF conceived and wrote the first draft of the manuscript while GDA, RMC, KKN made editorial contributions and were major contributors in the writing of the manuscript. All authors read and approved the final manuscript.

\section{Funding}

Not applicable.

Availability of data and materials Not applicable. 


\section{Declarations}

\section{Ethics approval and consent to participate}

Ethics approval is not applicable. All authors consented to participate in writing the manuscript.

\section{Consent for publication}

All authors consented to publish the manuscript.

\section{Competing interests}

The authors declare that they have no competing interests.

Received: 8 October 2021 Accepted: 16 October 2021

Published online: 04 December 2021

\section{References}

Abera B (2014) Medicinal plants used in traditional medicine by Oromo people, Ghimbi District, Southwest Ethiopia. J Ethnobiol Ethnomed 10(1):40 https://doi.org/10.1186/1746-4269-10-40

Adriaens EL (1951) Les oléagineux du Congo Belge (2 ème). Ministère des colonie, publication de la direction de l'agriculture et d'élevage

Aldous JC, Ellam GA, Murray V, Pike G (1994) An outbreak of illness among schoolchildren in London: toxic poisoning not mass hysteria. J Epidemiol Community Health 48(1):41-45. https://doi.org/10.1136/jech.48.1.41

Amuka O, Okemo PO, Machocho AK, Mbugua PK (2014) Ethnobotanical survey of selected medicinal plants used by Ogiek communities in Kenya against microbial infections. Ethnobot Res Appl. https://doi.org/10. 17348/era.12.0.627-641

Asfaw Z (1997) Conservation and use of traditional vegetables in Ethiopia. In: ICRAF-HQ (ed) Proceedings of the IPGRI international workshop on genetic resources of traditional vegetables in Africa conservation and use, pp 57-65

Berihun T, Molla E (2017) Study on the diversity and use of wild edible plants in Bullen District Northwest Ethiopia. J Bot. https://doi.org/10.1155/2017/ 8383468

Bosch CH (2004) Acanthosicyos naudinianus (Sond.) C. Jeffrey. Plant resources of tropical Africa 2. Vegetables2. PROTA Foundation, pp 31-34

Bruschi P, Morganti M, Mancini M, Signorini MA (2011) Traditional healers and laypeople: a qualitative and quantitative approach to local knowledge on medicinal plants in Muda (Mozambique). J Ethnopharmacol. https://doi. org/10.1016/j.jep.2011.09.055

Bunalema L, Obakiro S, Tabuti JRS, Waako P (2014) Knowledge on plants used traditionally in the treatment of tuberculosis in Uganda. J Ethnopharmacol. https://doi.org/10.1016/j.jep.2013.12.020

Chambliss OL, Jones CM (1966) Chemical and genetic basis for insect resistance in cucurbits. Am Soc Hortic Sci 89:394-405

Chan K, Zhang HW, Lin TX (2014) Treatments used in complementary and alternative medicine. In: Aronson JK (ed) Side effects of drugs annual, vol 35, 1st edn. Elsevier, Amsterdam, pp 889-898. https://doi.org/10.1016/ S0378-6080(09)03148-1

Cheikhyoussef A, Shapi M, Matengu K, Mu Ashekele H (2011) Ethnobotanical study of indigenous knowledge on medicinal plant use by traditional healers in Oshikoto region, Namibia. J Ethnobiol Ethnomed 7(1):10. https://doi.org/10.1186/1746-4269-7-10

Chinsembu KC, Hijarunguru A, Mbangu A (2015) Ethnomedicinal plants used by traditional healers in the management of HIV/AIDS opportunistic diseases in Rundu, Kavango East Region, Namibia. S Afr J Bot 100:33-42. https://doi.org/10.1016/j.sajb.2015.05.009

Cocks ML, Dold AP (2006) Cultural significance of biodiversity: the role of medicinal plants in Urban African cultural practices in the Eastern Cape, South Africa. J Ethnobiol. https://doi.org/10.2993/0278-0771(2006)26[60: CSOBTR]2.0.CO;2

Constant NL, Tshisikhawe MP (2018) Hierarchies of knowledge: ethnobotanical knowledge, practices and beliefs of the Vhavenda in South Africa for biodiversity conservation. J Ethnobiol Ethnomed 14(1):56. https://doi.org/ 10.1186/s13002-018-0255-2

de Wet H, Ramulondi M, Ngcobo ZN (2016) The use of indigenous medicine for the treatment of hypertension by a rural community in northern
Maputaland, South Africa. S Afr J Bot. https://doi.org/10.1016/j.sajb.2015. 08.011

Desouter S (1991) Human and veterinary pharmacopoeia. Tervuren 22:252

Deutschländer MS, Lall N, van de Venter M (2009) Plant species used in the treatment of diabetes by South African traditional healers: an inventory. Pharm Biol 47(4):348-365. https://doi.org/10.1080/13880200902752959

Dhiman K, Gupta A, Sharma DK, Gill NS, Goyal A (2012) A review on the medicinally important plants of the family Cucurbitaceae. Asian Journal of Clinical Nutrition 4(1):16-26. https://doi.org/10.3923/ajen. 2012.16.26

Gelmesa D (2010) Shifting to alternative food source: potential to overcome Ethiopias malnutrition and poverty problems. ISDA, New York

Gomez MI (1989) A resource inventory of indigenous and traditional foods in Zimbabwe. University of Zimbabwe Publications, Harare

Grosskinsky B, Gullick C (1999) Exploring the potential of indigenous wild food plants in Southern Sudan. In: Workshop proceedings, pp 17-42

Hansan JR (1985) Terpenoids. In: Thompson RH (ed) The chemistry of natural products. Blackie, Glasgow

Hart T, Vorster I (2006) Indigenous knowledge on the South African landscape: potentials for agricultural development. HSRC Press, Bloemfontein. https://doi.org/10.35638/JIH.2007..2.015

Hilonga S, Otieno JN, Ghorbani A, Pereus D, Kocyan A, de Boer H (2019) Trade of wild-harvested medicinal plant species in local markets of Tanzania and its implications for conservation. S Afr J Bot. https://doi. org/10.1016/j.sajb.2018.08.012

Irakiza R, Vedaste M, Elias B, Nyirambangutse B, Serge NJ, Marc N (2016) Assessment of traditional ecological knowledge and beliefs in the utilisation of important plant species: The case of Buhanga sacred forest, Rwanda. Koedoe. https://doi.org/10.4102/koedoe.v58i1.1348

Isabirye J (2019) Sustainability of the Bigwala musical heritage of Busoga Kingdom in Uganda. https://hdl.handle.net/20.500.12504/344

Issali AE, Mpika J, Mokolo JB, Attibayeba P (2020) Response of Cucurbitaceae seedlings, Cucurbita mochata, Cucurbita pepo and Lagenaria siceraria to the fertilization by pig dejecta at Brazzaville, Congo. J Appl Biosci 150:15469-15476. https://doi.org/10.35759/JABs.150.7

Kasali FM, Mahano AO, Nyakabwa DS, Kadima NJ, Misakabu FM, Tshibangu DST, Ngbolua KN, Mpiana PT (2014) Ethnopharmacological survey of medicinal plants used against malaria in Bukavu City (D. R. Congo). Eur J Med Plants 4(1):29-44. https://doi.org/10.9734/ejmp/2014/5766

Khan SA, Shelleh HH, Bhat AR, Bhat KS (2003) Colocynth toxicity. A possible cause of bloody diarrhea. Saudi Med J 24:904-906

Lavie D, Willner D, Merenlender Z (1964) Constituents of Citrullus colocynthis (L.) Schrad. Phytochemistry 3(1):51-56. https://doi.org/10.1016/S00319422(00)83994-1

Leffers A (2003) Gemsbok bean and Kalahari truffle: traditional plant use. In Jul'Hoansi (ed) North-eastern Namibia. Gamsberg MacMillan Publishers, Windhoek, p 202

Lindh $\mathrm{H}$ (2015) Mothers, markets and medicine: the role of traditional herbal medicine in primary women and child health care in the Dar es Salaam region, Tanzania. Volume Independent. http://uu.diva-portal.org/ smash/get/diva2:1066900/FULLTEXT01.pdf

Mabogo DEN (1990) The ethnobotany of the Vhavenda. Magister Scientiae in the Faculty of Science (Department of Botany) Thesis, University of Pretoria (1990)

Maroyi A (2012) Local plant use and traditional conservation practices in Nhema communal area, Zimbabwe. Int J Afr Renaiss Stud Multi- InterTransdiscipl. https://doi.org/10.1080/18186874.2012.699934

Maundu P, Achigan-Dako E, Morimoto Y (2009) Biodiversity of African vegetables. Afr Indig Veg Urban Agric. https://doi.org/10.4324/97818 49770019

Meragiaw M, Asfaw Z, Argaw M (2016) The status of ethnobotanical knowledge of medicinal plants and the impacts of resettlement in Delanta, Northwestern Wello, Northern Ethiopia. Evid Based Complement Altern Med. https://doi.org/10.1155/2016/5060247

Msuya TS, Kideghesho JR, Mosha TCE (2010) Availability, preference, and consumption of indigenous forest foods in the eastern arc mountains, Tanzania. Ecol Food Nutr. https://doi.org/10.1080/03670241003766048

Nadkarni N, D'Cruz S, Sachdev A (2010) Hematemesis due to bitter melon (Momordica charantia) extract-induced gastric ulcerations. Indian J Gastroenterol 29(1):43-44. https://doi.org/10.1007/s12664-010-0009-0 
Ng TJ (1993) New opportunities in the Cucurbitaceae. In: Janick J, Simon JE (eds) New crops. Wiley, Hoboken, pp 538-546

Ngbolua K, Mihigo SO, Liyongo Cl, Masengo CA, Tshibangu DST, Zoawe BG, Baholy R, Fatiany PR, Mpiana PT (2016) Ethno-botanical survey of plant species used in traditional medicine in Kinshasa city (Democratic Republic of the Congo). Trop Plant Res 3(2):413-427

Ngugi G, Grosskinski B, Gullick C (1999) Case study from Kenya on indigenous wild vegetables. In: Proceedings of workshop: exploring the potential of indigenous wild food plants in Southern Sudan. Lokichoggio, Kenya

Puri R, Sud R, Khaliq A, Kumar M, Jain S (2011) Gastrointestinal toxicity due to bitter bottle gourd (Lagenaria siceraria) - a report of 15 cases. Indian J Gastroenterol 30(5):233-236. https://doi.org/10.1007/s12664-011-0110-z

Ruffo CK, Birnie A, Tenganäs B (2002) Edible wild plants of Tanzania. In: Technical handbook No. 27 (Issue 27)

Salinitro M, Vicentini R, Bonomi C, Tassoni A (2017) Traditional knowledge on wild and cultivated plants in the Kilombero Valley (Morogoro Region, Tanzania). J Ethnobiol Ethnomed. https://doi.org/10.1186/s13002-017-0146-y

Schaefer H, Renner SS (2010) A gift from the new world? The West African crop Cucumeropsis mannii and the American Posadaea sphaerocarpa (Cucurbitaceae) are the same species. Syst Bot. https://doi.org/10.1600/ 036364410792495818

Schaefer H, Renner SS (2011) Cucurbitaceae. In: Kubitzki K (ed) Families and genera of flowering plants, 10th edn. Springer, Berlin, pp 112-174

Schaffer AA, Paris HS (2003) Melons, squashes, and gourds. In: Encyclopedia of food sciences and nutrition, pp 3817-3826. https://doi.org/10.1016/ b978-0-08-100596-5.03426-0

Scheub H (1985) A review of African oral traditions and literature. Afr Stud Rev. https://doi.org/10.2307/524603

Semenya SS, Maroyi A (2018) Plants used by Bapedi traditional healers to treat asthma and related symptoms in Limpopo Province, South Africa. Evid Based Complement Altern Med. https://doi.org/10.1155/2018/2183705

Semenya SS, Potgieter MJ, Erasmus LJC (2013) Exotic and indigenous problem plants species used, by the Bapedi, to treat sexually transmitted infections in Limpopo Province, South Africa. Afr Health Sci. https://doi.org/10. 4314/ahs.v13i2.17

Shiracko N, Owuor BO, Gakuubi MM, Wanzala W (2016) A survey of ethnobotany of the AbaWanga people in Kakamega County, western province of Kenya. Indian J Trad Knowl 15(1):93-102

Tebkew M, Gebremariam Y, Mucheye T, Alemu A, Abich A, Fikir D (2018) Uses of wild edible plants in Quara district, northwest Ethiopia: implication for forest management. Agric Food Secur. https://doi.org/10.1186/ s40066-018-0163-7

Teffera T (2006) The role of traditional music among East African Societies 1. Tautosakos Darbai XXXII:36-49

Teklehaymanot T, Giday M (2010) Ethnobotanical study of wild edible plants of Kara and Kwego semi-pastoralist people in Lower Omo River Valley, Debub Omo Zone, SNNPR, Ethiopia. J Ethnobiol Ethnomed. https://doi. org/10.1186/1746-4269-6-23

Toteja G, Satyanarayana K, Sharma S, Jain A, Sharma A, Gupta Y, Dwivedi S, Prasad M, Dohroo N, Sesikeran B, Tandon N, Puri R, Sharma M, Bohra S, Saraya A, Gupta K, Pandey J, Tandon N, Dorle A, Tandon N, Handa SS, Toteja GS, Rao S, Satyanarayana K, Katoch V (2012) Assessment of effects on health due to consumption of bitter bottle gourd (Lagenaria siceraria) juice. Indian J Med Res 135(1):49. https://doi.org/10.4103/0971-5916. 93424

Tugume P, Kakudidi EK, Buyinza M, Namaalwa J, Kamatenesi M, Mucunguzi P, Kalema J (2016) Ethnobotanical survey of medicinal plant species used by communities around Mabira Central Forest Reserve, Uganda. J Ethnobiol Ethnomed. https://doi.org/10.1186/s13002-015-0077-4

Usman JG, Sodipo OA, Kwaghe A, Sandabe UK (2015) Uses of Cucumis metuliferus: a review. Cancer Biol 5:24

van Rooyen N (2001) Flowering plants of the Kalahari Dunes. Ekotrust. https:// books.google.co.za/books?id=6B9FAQAAIAAJ

van Wyk BE (2011) The potential of South African plants in the development of new food and beverage products. S Afr J Bot. https://doi.org/10.1016/j. sajb.2011.08.003

Verdcourt B, Trump EC (1969) Common poisonous plants of East Africa. Collins, New York

Watt JM, Breyer-Brandwijk MG (1962) The medicinal and poisonous plants of Southern and Eastern Africa. E \& S Livingstone, London
Wickens GE, Burkill HM (1986) The useful plants of West Tropical Africa. In: Kew bulletin, 2nd ed, vol 41(2). Royal Botanic Gardens. https://doi.org/10. $2307 / 4102963$

Wilkins-Ellert MH (2004) Acanthosicyos horridus Welw. ex Hook. f. In Grubben GJH, Denton OA (eds) Plant resources of Tropical Africa 2. PROTA Foundation, pp 31-34

\section{Publisher's Note}

Springer Nature remains neutral with regard to jurisdictional claims in published maps and institutional affiliations.

\section{Submit your manuscript to a SpringerOpen ${ }^{\circ}$ journal and benefit from:}

- Convenient online submission

- Rigorous peer review

- Open access: articles freely available online

- High visibility within the field

- Retaining the copyright to your article

Submit your next manuscript at $\boldsymbol{\nabla}$ springeropen.com 